\title{
A TALE OF TWO HYPOGLYCEMICS
}

Kerri McGreal, MD and Leigh Eck, MD

Department of Internal Medicine, University of Kansas, Kansas City, KS

\section{OBJECTIVE}

To understand the work up of hyperinsulinemic hypoglycemia by comparing two cases of very different etiologies.

\section{INTRODUCTION}

Hypoglycemia in the absence of glucose lowering medications is uncommon. The first step in

evaluating hypoglycemia is to confirm fulfillment of Whipples' triad. Standard hypoglycemic labs then must be obtained when the glucose is $<55 \mathrm{mg} / \mathrm{dL}$. Data obtained at the time of a hypoglycemic event allows for determination of the etiology. We present two different cases of hyperinsulinemic hypoglycemia.

\section{CASE PRESENTATION}

Case 1: A 38 year old female presented with a 10year history of light headedness if she skipped meals. Additional symptoms included fatigue, irritability and forgetfulness most prominent in the early morning hours. On self monitoring of blood glucose, she obtained fasting glucose values of $43 \mathrm{mg} / \mathrm{dL}$ to $54 \mathrm{mg} / \mathrm{dL}$. She was admitted for a 72 hour fast with lab findings seen in Table 1. In light of concern for an insulinoma, a CT of the abdomen (Figure 1) was obtained which revealed a briskly enhancing mass within the pancreatic head measuring $1.1 \times 1.4 \mathrm{~cm}$. Enucleation of this insulinoma was successfully performed with resolution of hypoglycemia.

Case 2: A 41 year old female with a long standing history of diabetes mellitus type 2 requiring insulin was admitted with hypoglycemia. Due to persistent hypoglycemia despite stopping all exogenous insulin use, a hypoglycemic evaluation was undertaken and labs are seen in table 1. Her lab work was consistent with surreptitious administration of insulin. This patient's hypoglycemia resolved after we reviewed our findings with her and addressed our concern for factitious hypoglycemia.

\begin{tabular}{|llllll|} 
& Glucose & C-Peptide & Insulin & BOHB $^{*}$ & OHP** $^{\text {** }}$ \\
\hline Case 1 & $41 \mathrm{mg} / \mathrm{dl}$ & $1.3 \mathrm{ng} / \mathrm{ml}$ & $6.6 \mathrm{mcu} / \mathrm{ml}$ & Not done & Negative \\
\hline Case 2 & $45 \mathrm{mg} / \mathrm{dl}$ & $0.5 \mathrm{ng} / \mathrm{ml}$ & $71.8 \mathrm{mcu} / \mathrm{ml}$ & $0.1 \mathrm{mmol} / \mathrm{l}$ & Negative \\
& & & & & \\
\hline
\end{tabular}

Table 1. Hypoglycemic laboratory evaluation. * $\beta$-hydroxybutyrate * Oral Hypoglycemic Pan

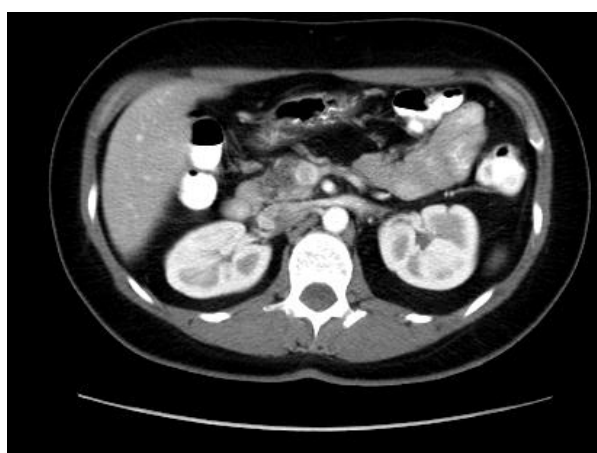

Figure 1. CT scan with briskly enhancing mass within pancreatic head.

\begin{tabular}{|c|c|c|c|c|}
\hline & Glucose & C-peptide & Insulin & OHP \\
\hline Insulinoma & 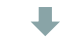 & 수 & 个 & ש \\
\hline $\begin{array}{l}\text { Exogenous } \\
\text { insulin }\end{array}$ & $V$ & 7 & 수 & - \\
\hline $\begin{array}{l}\text { SU } \\
\text { overdose }\end{array}$ & $\checkmark$ & 1 & 1 & t \\
\hline
\end{tabular}

hyperinsulinemic hypoglycemia

\section{REFERENCES}

1. Cryer PE, Axelrod L, Grossman AB, et al. Evaluation and management of adult hypoglycemic disorders: an Endocrine Society Clinical Practice Guideline. J Clin Endocrinol Metab 2009: 94:709.

2. Mathur A, Gorden P, and Libutti SK. Insulinoma. Surg Clin N Am 2009; 891105 1121

3. Service FJ. Hypoglycemic disorders. N Engl J Med 1995; 332:1144

\section{History}

COMPONENTS OF EVALUATION

It is important to confirm presence of hypolgycemia prior to an extensive laboratory evaluation. This is done by the documentation of Whipple's triad:

- symptoms consistent with hypoglycemia - $\quad$ with a concomitant low plasma glucose level

- relief of symptoms with treatment of hypoglycemia

\section{Laboratory Evaluation}

Once hypoglycemia is confirmed, a structured

laboratory evaluation should be undertaken at the time of hypoglycemia to include:

$\begin{array}{ll}\text { - } & \text { glucose } \\ \text { - } & \text { insulin } \\ \text { - } & \text { proinsulin } \\ \text { - } & \text { beta-hydroxybutyrate } \\ \text { - } & \text { oral hypoglycemic panel }\end{array}$

The differential for hyperinsulinemic hypoglycemia includes endogenous hyperinsulinemia (i.e insulinoma; nesideoblastosis), exogenous insulin exposure, oral hypoglycemic agents, and rarely, insulin antibodies. See figure 2 for interpretation of laboratory evaluation in hyperinsulinemic hypoglycemia.

\section{CONCLUSION}

Hypoglycemia not related to the management of diabetes mellitus is rare. A structured laboratory investigation at the time of an event is necessary to appropriately evaluate and then subsequently manage hypoglycemia. 